\title{
LANGKAH-LANGKAH PEMECAHAN MASALAH DAN KEMAMPUAN KOGNITIF
}

\author{
${ }^{1}$ Rakha Pradestya, ${ }^{2}$ Aritsya Imswatama, ${ }^{3}$ Pujia Siti Balkist \\ ${ }^{123}$ Program Studi Pendidikan Matematika, Fakultas Keguruan dan Ilmu Pendidikan, Universitas \\ Muhammadiyah Sukabumi \\ 1rpradestva@gmail.com \\ 2iaritsva@gmail.com \\ 3 puiliabalkist@ummi.ac.id
}

\begin{abstract}
ABSTRAK
Ide kajian teori ini muncul dari fenomena di sekolah tentang langkah-langkah pemecahan masalah dan kemampuan kognitif dari masing-masing siswa, khususnya di SMP Khalifah Boarding School. Setiap siswa memiliki proses pemecahan masalah yang berbeda satu sama lain dan menghadapi kesulitan yang berbeda-beda. Hasil dari kajian teori ini menunjukkan bahwa setiap langkahlangkah pemecahan masalah membutuhkan kemampuan kognitif yang berbeda-beda. Pada langkah pertama, yaitu memahami masalah. Memahami masalah membutuhkan dua kemampuan kognitif dasar, yaitu mengingat (C1) dan memahami (C2). Pada langkah ini, siswa diharuskan memiliki ingatan yang baik dan pemahaman yang mumpuni guna memahami masalah yang dihadapi. Pada langkah kedua, yaitu perencanaan pemecahan masalah. Dalam merencanakan pemecahan masalah, siswa harus bisa menerapkan konsep atau rumus yang diingat dan dipahami sebelumnya agar penyelesaian bisa tercapai. Maka dari itu, dalam merencanakan pemecahan masalah, siswa harus mencapai kemampuan kognitif yang ketiga yaitu menerapkan (C3). Pada langkah ketiga, yaitu menyelesaikan masalah sesuai rencana. Langkah ini adalah langkah yang menentukan apakah pemecahan masalah yang direncanakan benar atau tidak. Maka dari itu, pada langkah ini perlu adanya kemampuan menganalisis (C4) dan mengevaluasi (C5) yang baik. Daya analisis siswa pada langkah ini sangat dibutuhkan karena siswa dituntut untuk menyelesaikan masalah dengan tepat. Informasi yang didapat pada masalah harus lengkap dan cukup guna dimanfaatkan pada pemecahan masalah. Daya evaluasi siswa juga sangat penting pada langkah ini, karena pada proses penyelesaian, tidak bisa dipungkiri kemungkinan kesalahan dapat terjadi. Pada langkah terakhir, yaitu melihat kembali pemecahan masalah. Pada langkah ini, kemungkinan bisa teridentifikasi adanya konsep atau rumus baru yang tercipta pada pemecahan masalah. Maka dari itu, daya mencipta (C6) bisa diketahui pada langkah terakhir pemecahan masalah.
\end{abstract}

Kata Kunci: Kemampuan kognitif, pemecahan masalah

\section{PENDAHULUAN}

Ide kajian teori ini muncul dari fenomena di sekolah tentang langkahlangkah pemecahan masalah dan kemampuan kognitif dari masing-masing siswa, khususnya di SMP Khalifah Boarding School. Setiap siswa memiliki proses pemecahan masalah yang berbeda satu sama lain dan menghadapi kesulitan yang berbeda-beda. Kesulitan yang dihadapi oleh siswa bergantung pada kemampuan kognitif yang dimiliki. Kemampuan kognitif adalah kemampuan siswa dalam proses berpikir dan kemampuan pemecahan masalah. Menurut Huda (Susanti, 2018) kualitas pendidikan yang baik diperoleh dengan menerapkan semua tingkat ranah kognitif dalam setiap pembelajaran. Taksonomi Bloom ranah kognitif yang telah direvisi (Anderson, L.W., 2001) yakni: mengingat (remember), memahami/mengerti (understand), menerapkan (apply), menganalisis (analyze), mengevaluasi (evaluate), dan menciptakan (create). Berikut adalah karakteristik kemampuan kognitif siswa: 
Tabel 1. Indikator Kemampuan Kognitif

\begin{tabular}{|c|c|c|}
\hline $\begin{array}{l}\text { Kemampuan } \\
\text { Kognitif }\end{array}$ & Indikator & Kode \\
\hline $\begin{array}{l}\text { Mengingat } \\
\text { (Remember) }\end{array}$ & $\begin{array}{l}\text { Kemampuan mengingat kembali materi yang telah } \\
\text { dipelajari. Kata operasionalnya mengingat yaitu } \\
\text { mengutip, menyebutkan, } \\
\text { menggambarkan, membilang, } \\
\text { mengidentifikasi, mendaftar, }\end{array}$ & $\mathrm{C} 1$ \\
\hline $\begin{array}{l}\text { Memahami } \\
(\text { Understand) }\end{array}$ & $\begin{array}{l}\text { Kemampuan untuk memahami materi yang } \\
\text { telah dipelajari. }\end{array}$ & $\mathrm{C} 2$ \\
\hline $\begin{array}{l}\text { Menerapkan } \\
\text { (Apply) }\end{array}$ & $\begin{array}{l}\text { Pemahaman menuntut siswa untuk menunjukkan } \\
\text { bahwa mereka telah mempunyai pengertian yang } \\
\text { memadai untuk mengorganisasikan dan menyusun } \\
\text { materi-materi yang telah diketahui. Kata } \\
\text { operasionalnya mengklasifikasikan dan } \\
\text { menjelaskan. }\end{array}$ & $\mathrm{C} 3$ \\
\hline $\begin{array}{l}\text { Menganalisis } \\
\quad \text { (Analyze) }\end{array}$ & $\begin{array}{l}\text { Mencakup penggunaan suatu prosedur guna } \\
\text { menyelesaikan masalah atau mengerjakan tugas. } \\
\text { Prosesnyaa adalah menjalankan dan } \\
\text { mengimplementasikan. }\end{array}$ & $\mathrm{C} 4$ \\
\hline $\begin{array}{l}\text { Mengevaluasi } \\
\text { (Evaluate) }\end{array}$ & $\begin{array}{l}\text { Menguraikan suatu permasalahan keunsur- } \\
\text { unsurnya dan menentukan bagaimana saling } \\
\text { keterkaitan unsur tersebut. Kata } \\
\text { operasionalnya menyusun ulan. }\end{array}$ & $\mathrm{C} 5$ \\
\hline $\begin{array}{l}\text { Mencipta } \\
\text { (Create) }\end{array}$ & $\begin{array}{l}\text { Menguraikan suatu permasalahan keunsur- } \\
\text { unsurnya dan menentukan bagaimana saling } \\
\text { keterkaitan unsur tersebut. Kata } \\
\text { operasionalnya menyusun ulang. }\end{array}$ & C6 \\
\hline
\end{tabular}

Kesulitan yang dialami oleh masing-masing siswa tidak terlepas dari seberapa baiknya kemampuan kognitif siswa. Siswa mengalami kesulitan ketika siswa tersebut belum mencapai tingkatan kemampuan kognitif di atas. Hal ini dapat dilihat dari bagaimana siswa memecahkan masalah dengan memanfaatkan kemampuan kognitif yang dimiliki. Pemecahan masalah merupakan satu strategi kognitif yang diperlukan dalam kehidupan sehari-hari. Berpikir mengenai pemecahan masalah dapat membantu dalam dua alasan. Pertama, penekanan kesinambungan proses pemecahan masalah dengan cara kita bergerak dari keadaan awal hingga keadaan akhir dapat
Sumber: (Susanti, 2018)

dirumuskan secara lebih jelas. Kedua, berpikir mengenai pemecahan masalah merupakan salah satu proses perubahan dari satu keadaan pada keadaan lain yang dapat meningkatkan pemahaman. Masalah yang dihadapi dapat dipecahkan dengan menggunakan strategi yang bersifat umum.

Pemecahan masalah terhadap suatu masalah bisa jadi berbeda setiap siswa, karena kemampuan kognitif masing- masing siswa berbeda. Hal ini bergantung pada seberapa banyak struktur pengetahuan yang dimiliki oleh masingmasing siswa. Terdapat rumusan masalah yang "ill- defined problem" yaitu yang memiliki lebih dari satu solusi dan tidak bersifat universal. Adapula yang "welldefined problem" yaitu hanya memiliki 
satu solusi dan bersifat universal. Pemecahan masalah adalah kegiatan yang bertujuan untuk mencari solusi dari suatu permasalahan. Polya menyatakan bahwa pemecahan masalah adalah salah satu aspek berpikir tingkat tinggi. Sehingga Polya (Hartono, 2014: 2) mengemukakan dua macam masalah matematika yaitu : (1) Masalah untuk menemukan (problem to find) dimana kita mencoba untuk mengkontruksi semua jenis objek atau informasi yang dapat digunakan untuk menyelesaikan masalah tersebut, dan (2) Masalah untuk membuktikan (problem to prove) dimana kita akan menunjukan salah satu kebenaran pernyatan, yakni pernyatan itu benar atau salah. Masalah jenis ini mengutamakan hipotesis ataupun konklusi dari suatu teorema yang kebenaranya harus dibuktikan. Menurut Polya, siswa memiliki kemampuan pemecahan masalah yang baik jika sudah memenuhi indikator-indikator, yaitu:

a. Memahami masalah

b. Merencanakan penyelesaian

c. Menyelesaikan masalah sesuai rencana

d. Melakukan pengecekan kembali terhadap semua langkah yang telah dilakukan.

\section{PEMBAHASAN}

Kemampuan kognitif siswa akan mempengaruhi proses pemecahan masalah. Setiap langkah pada pemecahan masalah membutuhkan kemampuan kognitif yang sesuai. Maka dari itu, timbul pertanyaan "Kemampuan kognitif mana yang mempengaruhi proses pemecahan masalah?".

Hasil dari kajian teori ini menunjukkan bahwa setiap langkah- langkah pemecahan masalah membutuhkan kemampuan kognitif yang berbeda-beda. Pada langkah pertama, yaitu memahami masalah. Memahami masalah membutuhkan dua kemampuan kognitif dasar, yaitu mengingat (C1) dan memahami (C2). Pada langkah ini, siswa diharuskan memiliki ingatan yang baik dan pemahaman yang mumpuni guna memahami masalah yang dihadapi. Pada langkah kedua, yaitu perencanaan pemecahan masalah. Dalam merencanakan pemecahan masalah, siswa harus bisa menerapkan konsep atau rumus yang diingat dan dipahami sebelumnya agar penyelesaian bisa tercapai. Maka dari itu, dalam merencanakan pemecahan masalah, siswa harus mencapai kemampuan kognitif yang ketiga yaitu menerapkan (C3). Pada langkah ketiga, yaitu menyelesaikan masalah sesuai rencana. Langkah ini adalah langkah yang menentukan apakah pemecahan masalah yang direncanakan benar atau tidak. Maka dari itu, pada langkah ini perlu adanya kemampuan menganalisis (C4) dan mengevaluasi (C5) yang baik. Daya analisis siswa pada langkah ini sangat dibutuhkan karena siswa dituntut untuk menyelesaikan masalah dengan tepat. Informasi yang didapat pada masalah harus lengkap dan cukup guna dimanfaatkan pada pemecahan masalah. Daya evaluasi siswa juga sangat penting pada langkah ini, karena pada proses penyelesaian, tidak bisa dipungkiri kemungkinan kesalahan dapat terjadi. Pada langkah terakhir, yaitu melihat kembali pemecahan masalah. Pada langkah ini, kemungkinan bisa teridentifikasi adanya konsep atau rumus baru yang tercipta pada pemecahan masalah. Maka dari itu, daya mencipta (C6) bisa diketahui pada langkah terakhir pemecahan masalah.

Dari pembahasan di atas, dapat disimpulkan bahwa setiap pemecahan masalah membutuhkan kemampuan kognitif yang berbeda. Namun, kemampuan kognitif siswa berbeda satu sama lain. Kemampuan kognitif siswa bisa dikategorikan dengan predikat tinggi, sedang, dan rendah. Setiap predikat ini memiliki definisi masing-masing. Berikut ringkasannya: 
Tabel 2. Indikator Kemampuan Kognitif pada Langkah-LangkahPemecahan Masalah menurut Polya.

\begin{tabular}{|c|c|c|c|}
\hline $\begin{array}{c}\text { Pemecahan } \\
\text { Masalah }\end{array}$ & $\begin{array}{c}\text { Kemampuan } \\
\text { Kognitif }\end{array}$ & Deskripsi & Indikator \\
\hline (1) & (2) & (3) & (4) \\
\hline \multirow[t]{5}{*}{$\begin{array}{l}\text { Memahami } \\
\text { Masalah }\end{array}$} & \multirow[t]{3}{*}{ Mengingat } & \multirow[t]{3}{*}{$\begin{array}{lr}\text { Mengenali apa yang } \\
\text { diketahui } & \text { dari } \\
\text { permasalahan } & \end{array}$} & $\begin{array}{l}\text { Tinggi } \\
\text { Siswa dapat mengenali lebih } \\
\text { dari satu informasi dari } \\
\text { permasalahan } \\
\text { dengan benar. }\end{array}$ \\
\hline & & & \begin{tabular}{l} 
Sedang \\
Siswa dapat mengenali satu \\
\multicolumn{1}{c}{ informasi $\quad$ dari } \\
permasalahan \\
benar.
\end{tabular} \\
\hline & & & $\begin{array}{l}\text { Rendah } \\
\text { Siswa dapat mengenali satu } \\
\text { informasi dari permasalahan } \\
\text { tetapi kurang tepat. }\end{array}$ \\
\hline & \multirow[t]{2}{*}{ Memahami } & \multirow[t]{2}{*}{$\begin{array}{l}\text { Memahami } \\
\text { pertanyaan dan } \\
\text { penggunaan rumus } \\
\text { atau } \\
\text { konsep yang tepat }\end{array}$} & $\begin{array}{l}\text { Tinggi } \\
\text { Siswa memahami } \\
\text { pertanyaan } \\
\text { dimaksud dan yang } \\
\text { mengingat lebih dari satu } \\
\text { rumus atau konsep yang } \\
\text { berkaitan dengan } \\
\text { soal dengan benar. }\end{array}$ \\
\hline & & & 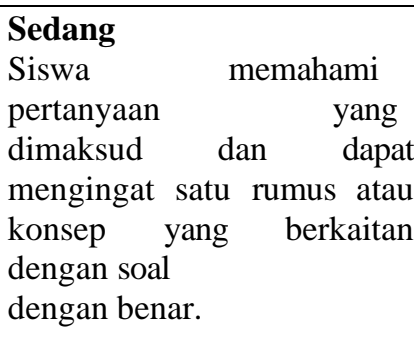 \\
\hline
\end{tabular}




\begin{tabular}{|l|l|l|} 
& & $\begin{array}{l}\text { Rendah } \\
\text { Siswa tidak memahami } \\
\text { pertanyaan yang } \\
\text { dimaksud dan tidak dapat } \\
\text { mengingat satu rumus atau } \\
\text { konsep pun Adapun } \\
\text { mengingat rumus atau } \\
\text { konsep yang berkaitan } \\
\text { dengan soal, } \\
\text { namun tidak benar. }\end{array}$ \\
\hline & Menerapkan & Tinggi \\
\hline
\end{tabular}

\begin{tabular}{|c|c|c|c|}
\hline \multirow[t]{3}{*}{$\begin{array}{l}\text { Perencanaan } \\
\text { pemecahan } \\
\text { masalah }\end{array}$} & & \multirow[t]{3}{*}{$\begin{array}{l}\text { Dapat } \\
\text { mengimplementas } \\
\text { ikan rumus atau } \\
\text { konsep }\end{array}$} & $\begin{array}{l}\text { Siswa dapat } \\
\text { mengimplementasikan lebih } \\
\text { dari rumus atau konsep } \\
\text { dengan benar }\end{array}$ \\
\hline & & & $\begin{array}{l}\text { Sedang } \\
\text { Siswa dapat } \\
\text { mengimplementasikan satu } \\
\text { rumus atau konsep dengan } \\
\text { benar }\end{array}$ \\
\hline & & & $\begin{array}{l}\text { Rendah } \\
\text { Siswa dapat } \\
\text { mengimplementasikan satu } \\
\text { rumus atau konsep tetapi } \\
\text { kurang tepat }\end{array}$ \\
\hline \multirow[t]{3}{*}{$\begin{array}{l}\text { Menerapkan } \\
\text { pemecahan } \\
\text { masalah }\end{array}$} & \multirow[t]{3}{*}{ Menganalisis } & \multirow[t]{3}{*}{$\begin{array}{l}\text { Dapat menguraikan } \\
\text { proses pemecahan } \\
\text { masalah }\end{array}$} & $\begin{array}{l}\text { Tinggi } \\
\text { Siswa dapat } \\
\text { menguraikan penyelesaian } \\
\text { menggunakan lebih dari Satu } \\
\text { rumus atau konsep } \\
\text { dengan benar }\end{array}$ \\
\hline & & & $\begin{array}{l}\text { Sedang } \\
\text { Siswa dapat } \\
\text { menguraikan penyelesaian } \\
\text { menggunakan satu } \\
\text { rumus atau konsep dengan } \\
\text { benar }\end{array}$ \\
\hline & & & $\begin{array}{l}\text { Rendah } \\
\text { Siswa dapat } \\
\text { menguraikan penyelesaian } \\
\text { menggunakan rumus } \\
\text { atau konsep yang salah. }\end{array}$ \\
\hline
\end{tabular}




\begin{tabular}{|c|c|c|c|}
\hline & Mengevaluasi & $\begin{array}{l}\text { Memeriksa hasil } \\
\text { pemecahan masalah }\end{array}$ & $\begin{array}{l}\text { Tinggi } \\
\text { Siswa dapat memeriksa } \\
\text { lebih dari satu cara hasil } \\
\text { pekerjaannya dengan benar. }\end{array}$ \\
\hline & & & $\begin{array}{l}\text { Sedang } \\
\text { Siswa dapat memeriksa satu } \\
\text { cara hasil dengan } \\
\text { benar }\end{array}$ \\
\hline & & & $\begin{array}{l}\text { Rendah } \\
\text { Siswa tidak dapat memeriksa } \\
\text { hasil } \\
\text { pekerjaannya. }\end{array}$ \\
\hline $\begin{array}{l}\text { Melihat } \\
\text { kembali }\end{array}$ & Mencipta & $\begin{array}{l}\text { Mampu membuat atau } \\
\text { menemukan } \\
\text { rumus atau }\end{array}$ & $\begin{array}{l}\text { Tinggi } \\
\text { Siswa dapat membuat konsep } \\
\text { baru }\end{array}$ \\
\hline
\end{tabular}

\begin{tabular}{|l|l|l|l|}
\hline pemecahan & konsep baru atau \\
masalah & $\begin{array}{l}\text { konsep y yang } \\
\text { sebelumnya belum } \\
\text { diketahui }\end{array}$ & $\begin{array}{l}\text { Sedang } \\
\text { Siswa } \\
\text { menemukan }\end{array}$ \\
\cline { 3 - 4 } & & $\begin{array}{l}\text { Rendah } \\
\text { Siswa tidak membuat atau } \\
\text { menemukan }\end{array}$ \\
\hline
\end{tabular}




\section{KESIMPULAN}

Berdasarkan hasil kajian teori di atas, dapat disimpulkan bahwa:

a. Pada langka pertama yaitu memahami masalah, kemampuan kognitif yang diperlukan adalah kemampuan mengingat (C1) dan memahami (C2)

b. Pada langkah kedua yaitu perencanaan pemecahan masalah, kemampuan kognitif yang diperlukan adalah kemampuan menerapkan (C3)

c. Pada langkah ketiga yaitu menyelesaikan masalah sesuai rencana, kemampuan kognitif yang diperlukan adalah kemampuan menganalisis

d. Pada langkah keempat yaitu melihat kembali pemecahan masalah, kemampuan kognitif yang bisa diidentifikasi adalah kemampuan mencipta (C6)

\section{DAFTAR PUSTAKA}

Ananingsih, S. (2017). Pengaruh Kecerdasan Logis-Matematis terhadap Prestasi Belajar Matematika materi Luas Bangun Data Kelas $V$ di SD Muhammadiyah 09 Malang.

Skripsi Sarjana untuk FITK UIN Sultan Malik Ibrahim Malang: tidak diterbitkan.

Marliani, N. 2015. Kemampuan Pemecahan Masalah Matematis pada Mata Kuliah Persamaan Differensial dilihat dari Pembelajaran Konflik Kognitif yang Terintegrasi dengan Soft Skill. Jurnal Formatif. 5, (2), 134144

Nasution, A.U. dan Asmin. (2017). Perbedaan Kemampuan Pemecahan Masalah Matematis Siswa Menggunakan Model STAD dan Pembelajaran Langsung. Jurnal
Inspiratif. 3, (2), 29-36

Puspadewi, K.R. 2012. Pengaruh Model Pembelajaran Ikrar berorientasi Kearifan Lokal dan Kecerdasan Logis Matematis terhadap Kemampuan Pemecahan Masalah Matematika

Putra, H.D. et al. (2018). "Kemampuan Pemecahan Masalah Matematis Siswa pada Materi Bangun Ruang”. Jurnal Ilmiah Pendidikan Matematika. 6, (2), 82-90.

Setiadi, D. (2017). Kemampuan Berpikir Logis Matematis Siswa pada

(C4) dan mefmededpiasanÇ̧yngun Ruang dengan menggunakan Strategi Problem Solving di kelas IX SMPN 2 Mataraman Tahun Ajaran 2016/2017. Skripsi Sarjana pada FTK IAIN Antasari Banjarmasin: tidak diterbirkan.

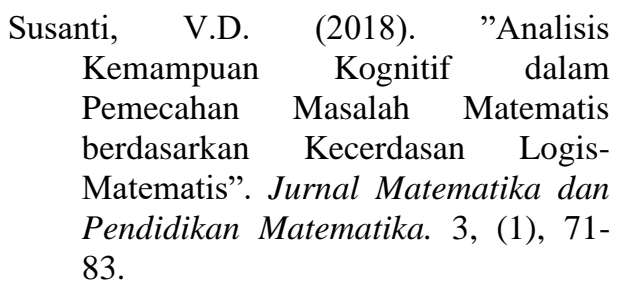

Ulya, H. (2015). "Hubungan Gaya Kognitif dengan Kemampuan Pemecahan Masalah Siswa". Jurnal Konseling GUSJIGANG. 1, (2 